BEZERRA, RS; EVANGELISTA, AWP; ALVES JÚNIOR, J; NASCIMENTO, AR; CASAROLI, D. 2018. Minitomato cultivation with substrate under different fertigation management strategies. Horticultura Brasileira 36: 088-093. DOI - http://dx.doi.org/10.1590/S0102-053620180115

\title{
Minitomato cultivation with substrate under different fertigation management strategies
}

\author{
Ricardo S Bezerra; Adão Wagner P Evangelista; José Alves Júnior; Abadia R Nascimento; Derblai Casaroli
}

Universidade Federal de Goiás (UFG), Goiânia-GO, Brazil; rsbezerra.agro@gmail.com; awpego@pq.cnpq.br; josealvesufg@yahoo.com. br; abadiadosreis@ufg.br; derblai@ufg.br

\begin{abstract}
The application of high level of fertilization and inadequate management of fertigation in tomato crop can promote increase of salinity of the solution, nutritional imbalance and physiological disorders in the plants, consequently reduces the productivity and the quality of the fruits. The aim of this study was to evaluate different fertigation strategies in growth and production of mini tomato plants cultivated with substrate in a greenhouse. The experimental design was in randomized complete blocks with four treatments and twenty replicates. The treatments corresponded to four fertigation strategies, as follows: T1 [(control) fertigation with leaching of $20 \%$ ]; T2 fertigation throughout the day and irrigation at the end of the day with leaching of $20 \%$; T3 irrigation with leaching of $20 \%$, followed by fertigation in all activations of the irrigation system; T4 fertigation with leaching of $20 \%$ and reuse of the leached solution. Stem height and diameter, number of clusters, total and commercial fruit production, fruit size, fruit color, total titratable acidity, soluble solids content and fruit texture were evaluated. No significant differences were detected among the treatments in relation to the growth variables of the mini tomato plants. The strategies of fertigation tested do not influence significantly the growth of tomato plants. The T1 and T4 managements provide higher commercial production and fruits with higher content of soluble solids when compared with other management strategies evaluated. Considering the nutritional factor, we recommend to reuse the nutrient solution used in the tomato cultivation with substrate, correcting daily the electrical conductivity of the solution.
\end{abstract}

Keywords: Solanum lycopersicum, salinity, leaching.

\section{RESUMO}

Cultivo de minitomate em substrato sob diferentes estratégias de manejo da fertirrigação

A aplicação de elevado nível de adubação e o manejo inadequado da fertirrigação no cultivo de tomateiro podem promover aumento da salinidade da solução, desequilíbrio nutricional e desordens fisiológicas nas plantas, com conseqüente redução de produtividade e qualidade dos frutos. Objetivou-se avaliar diferentes estratégias de fertirrigação no crescimento e produção de minitomates cultivados em vasos com substrato em casa de vegetação. $\mathrm{O}$ delineamento experimental foi em blocos ao acaso com quatro tratamentos e vinte repetições. Os tratamentos corresponderam a quatro manejos da fertirrigação: T1 [(testemunha) fertirrigação com lixiviação de 20\%]; T2 fertirrigação ao longo do dia e irrigação no final do dia com lixiviação de $20 \%$; T3 irrigação com lixiviação de $20 \%$, seguida de fertirrigação em todos os acionamentos do sistema de irrigação; T4 fertirrigação com lixiviação de $20 \%$ e reuso da solução lixiviada. Avaliaram-se altura e diâmetro da haste, número de cachos, produção total e comercial de frutos, tamanho, coloração, acidez total titulável, teor de sólidos solúveis e textura de frutos. Não foram detectadas diferenças significativas entre os tratamentos em relação às variáveis de crescimento do minitomate. Os manejos de fertirrigação testados não influenciam significativamente o crescimento do tomateiro. Os manejos T1 e T4 proporcionam maior produção comercial e frutos com maior teor de sólidos solúveis em relação às demais estratégias de manejo avaliadas. Considerando o fator nutricional, recomenda-se a reutilização da solução nutritiva usada no cultivo do tomateiro em substrato, corrigindo-se diariamente a condutividade elétrica da solução.

Palavras-chave: Solanum lycopersicum, salinidade, lâmina de lixiviação.

Received on March 23, 2016; accepted on April 20, 2017

$\mathrm{M}$ ini tomato cultivation has increased significantly in recent years in order to meet the growing demand for different vegetables in the market of big cities in Brazil. Minitomato is commonly grown in a protected environment and in pots containing substrate. In order to exploit the full productive potential of the cultivars currently existing, careful drip irrigation management and fertilizer application at right time and in correct quantity are important (Alvarenga, 2013).

Producers have been facing problems in cultivating minitomatoes mainly due to nutritional imbalance and physiological disorders of the plants, which frequently result in a decrease of productivity and, consequently, economic losses. The causes of these problems are mainly related to a high level of fertilizer application and to an inappropriate irrigation management, especially when cultivating the plants in pots (Furlani et al., 2013). The increase in salinity of the substrate solution reduces plant development and the quality of tomatoes (Magán et al., 2008).

Among the techniques normally proposed to avoid problems related to salinity, splitting scheme of nutrient supply to plants via fertigation has been the most effective (Fernandes et al., 2007), and it may provide nutrient savings over $25 \%$ in relation 
to conventional fertigation system (Alvarenga, 2013). Another proposed technique, when cultivating the plants in pots in greehouses, consists of applying an additional volume of nutrient solution which promotes drainage of part of the solution applied aiming to leach the excess of salts accumulated and avoid increasing salinity or cause nutritional imbalance of the plants (Katerji et al., 2003).

In order to calculate leaching depth, the authors used the electrical conductivity of the nutrient solution applied in fertigation and the average electrical conductivity of the saturation extract, corresponding to the ability of the crop to tolerate salinity, which is $2.5 \mathrm{dS} \mathrm{m}^{-1}$ for tomato (Ayers \& Westcot, 1985). However, most farmers have adopted practical values, with no proven technical foundations.

The reuse of nutrient solution leached from the pots is a management strategy which avoids fertilizer disposal into the soil, consequently it avoids soil and water contamination. Additionally, this strategy allows significant economic benefits, since it reduces fertilizer waste, as well as waste water and energy (Rodrigues, 2002). Among the disadvantages on reusing leached nutrient solution, the authors highlight negative effects on nutritional imbalance which may occur in the system and risks of rapid dissemination of root diseases in the production system (Furlani et al., 2013), considering that only one diseased plant can contaminate all other plants due to the propagation of pathogens through the nutrient solution used in closed fertigation systems.

Another management strategy used by minitomato farmers, in order to decrease adverse effects of salinity, is to apply sufficient amount of water periodically to cause percolation of the solution at the bottom of the pot. According to Magán et al. (2008), such strategy does not present any technical criterion at all and shows uncertain results.

The aim of this work was to evaluate the effect of different fertigation management strategies on the growth and development of minitomatoes, as well as the quality of the tomato fruits, cultivated in pots containing substrate.

\section{MATERIAL AND METHODS}

The experiment was performed in the experimental area at Universidade Federal de Goiás, from May to September 2015. The local climate is Aw type, according to Köppen classification, tropical with a well-defined dry season.

Cultivation was done in a greenhouse, chapel type, cover and both sides of polycarbonate, $6 \mathrm{~m}$ width, $10 \mathrm{~m}$ length, 3.2 ceiling height, with east-west orientation. Temperature and relative humidity were automatically controlled by an evaporative cooling air system, expanded clay-Panel Hood (pad-fan system). The environmental control system was programmed to maintain the air temperature around $25^{\circ} \mathrm{C}$ and relative air humidity at $65 \%$ (Alvarenga, 2013).

The experimental design was in complete randomized blocks with four treatments and five blocks. Each experimental unit consisted of one pot containing one mini tomato plant. Each block consisted of four pots of the same treatment randomly distributed, totaling twenty replicates. The treatments represented the following fertigaton management strategies: T1 [(control) fertigation with leaching of 20\%]; T2 fertigation throughout the day and irrigation at the end of the day with need of leaching of $20 \%$; T3 irrigation with need of leaching of $20 \%$, followed by fertigation in all activations of the irrigation system; T4 fertigation with need of leaching of $20 \%$ and reuse of the leached solution.

The authors used the indeterminate-growth-habit hybrid Mascot F1, belonging to the group of grape mini tomato variety. Seedlings were transplanted in 8-L plastic pots, 32 days after sowing (DAS), using one seedling per pot.

The pots were filled with commercial substrate (Amafibra, Golden Mix ${ }^{\circledR}$, tipo 11), consisting exclusively of coconut fiber, so that the apparent moisture content density of substrate reached $635.1 \mathrm{~g} \mathrm{~L}^{-1}$, equivalent to moisture content (Brasil, 2007), used in determining substrate water holding capacity. The pots were placed on metal benches ( $0.5 \mathrm{~m}$ height), containing a system to collect drained solution. Spacing among benches was of $1.0 \mathrm{~m}$ and among pots on the benches of 40 $\mathrm{cm}$.

The authors used drip irrigation system (emitter flow rate of $2 \mathrm{~L} \mathrm{~h}^{-1}$ ) with automatic irrigation control consisting of sensors for measuring water tension of the substrate (digital measuring center model Hidrosense ${ }^{\circledR}$ MRI with four channels and six sensors in each channel), programmable logic controller with eight outputs and solenoid valves. This irrigation system was developed in order to meet the needs of the experiment. The tension sensors with measuring ranging from 0 to $-15 \mathrm{kPa}$ were installed in six random pots of each treatment. The installation of the sensors in the substrates was done according to the recommendations of Calbo \& Silva (2005). The irrigation controller was programmed to record and to tore the water tension data in the substrate every three minutes and to apply the volume of nutrient solution and water according to each treatment. The frequency of application of nutrient solution and water was automatically set when the water tension of the substrate reached a critical value of $3 \mathrm{kPa}$.

In treatments $\mathrm{T} 1$ and $\mathrm{T} 4$, all fertigations, throughout the day, were carried out using sufficient volume to cause $20 \%$ leaching of the nutrient solution applied. In treatments $\mathrm{T} 2$ and $\mathrm{T} 3$, fertigations were done so that no leaching occurred, and only the irrigations performed exclusively with water were in sufficient quantity for leaching $20 \%$ of the total volume of water from each of these irrigations.

The duration of each fertigation was determined based on the average dripper flow rate, water holding capacity of the substrate and on the leaching fraction proposed in each treatment. The water irrigation depths were calculated considering water replacement volume in order to increase the water tension of the subtrate from $3 \mathrm{kPa}$ (critical tension used in the commercial substrate production systems of minitomates) to 1 $\mathrm{kPa}$ [maximum water holding capacity 
of the substrates (Fermino, 2014)] and the need of leaching the substrate solution.

The need for leaching was determined according to Ayers \& Westcot (1985):

$$
\mathrm{NL}=\frac{\text { CEsn }}{5 \text { (CEes) }- \text { CEsn }}
$$

in which: $\mathrm{NL}=$ need for leaching; $\mathrm{CEsn}=$ electrical conductivity of the nutrient solution $\left(\mathrm{dS} \mathrm{m}^{-1}\right)$ applied in fertigations $2.2 \mathrm{dS} \mathrm{m}^{-1}$; CEes $=$ average electrical conductivity of the saturation extract, corresponding to the salinity tolerated by the crop $\left(\mathrm{dS} \mathrm{m}^{-1}\right)$. For tomato, the authors adopted the value of $2.5 \mathrm{dS}$ $\mathrm{m}^{-1}$ (Ayers \& Westcot, 1985).

The standard nutrient solution used for fertigations was prepared with stock solutions proposed by Furlani et al. (2013), keeping electrical conductivity of the nutrient solution (EC) in 2.0 and $2.2 \mathrm{dS} \mathrm{m}^{-1}$ (Furlani et al., 2013) during the tomato vegetative and reproductive phases, respectively.

The nutrient solution used in fertigation treatment $\mathrm{T} 4$ was resulting from the mixture of leached solution of all the pots of treatment T4, water and stock solution used in the preparation of the standard nutrient solution. The leached solution of the pots was collected in containers put under the pots and would return manually to a specific tank; daily, the volume was completed with water and stock solution so that the parameters of the standard nutrient solution could be adjusted, according to the methodology proposed by Furlani et al. (2013).

Tutoring of branches was performed using ribbons, one stem per plant. Sprouting and removal of the leaves below the harvested clusters were carried out weekly. All the plants had their apical bud removed 69 days after transplanting (DAT) and chemical treatment for phitossanitary control were done every time insect-pests and diseases reached harmful levels for the plants.

The solution salinity was obtained through direct reading of electrical conductivity and $\mathrm{pH}$ of the leached nutrient solution, using a portable conductivity meter and a portable peagameter, and measurement of saline activity (AS) in the substrate. Saline activity in the substrate was measured directly in the substrate using HI 76305 probe (Hanna instruments) coupled to a portable conductivity meter. Readings were done with the probe in the substrate at an average depth of $11.5 \mathrm{~cm}$, equivalent to half the height of the pot, within a distance of $6 \mathrm{~cm}$, approximately, from the plant stem and arranged perpendicular to the dripper. Parameter AS in the substrate is related to, as EC of the solution in the substrate, the quantity of salts in the soil or substrate solution. The main advantage is the simplicity in the reading procedures as well as being a speed method for obtaining results, helping out assisting in decision-making process of fertigation management.

The authors evaluated the following plant growth traits: plant height $(27,48$ and 69 DAT); stem diameter (27 and 48 DAT); number of clusters with, at least, one open flower (69 DAT, full-ripe stage); and distance among consecutive clusters (27 and 48 DAT), considering up to the fifth cluster.

Harvests began at 59 DAT being done once a week, totaling nine harvests. Fruits were harvested when they presented completely red color. The authors determined the number of fruits per plant, and fresh mass of all fruits and total and commercial production per plant, number of fruits showing apical necrosis and number of small fruits. Fruit were classifyed in relation to the size, according to Fernandes et al. (2007). Cracked fruits, with apical necrosis and very small ones (less than $5 \mathrm{~g}$ ) were classified as unmarketable (Magán et al., 2008).

For fruits harvested at 94 DAT, at full-ripe stage, eight fruits with commercial standards were sampled, per plot (plant), in order to evaluate the following quality attributes: tegument coloring, soluble solids (brix), $\mathrm{pH}$ and total titratable acidity of the pulp, and resistance of tegument to puncture (texture). The external surface color of fruits was determined using color meter (Color Quest II, Hunter LabReston, Canada) (Paucar-Menacho et al., 2008). The color results were expressed in values of luminosity or brightness $\left(\mathrm{L}^{*}\right)$, chroma $\mathrm{a}^{*}$ and chroma $\mathrm{b}^{*}$. Total titratable acidity (AT), $\mathrm{pH}$ and Brix were determined using about one gram of crushed and homogenized raw pulp of eight fruits of each plant (Vieira et al., 2014).

In order to evaluate fruit texture, readings were made in samples of eight commercial fruits, per experimental unit, and then the average was calculated. One point in the equatorial region was punctured in the fruit using a texture analyzer(TA-XT Plus, Surrey, England). The authors used puncture normal force analysis, with deformation of $50 \%$ in relation to the initial height. The velocity of the probe before touching the fruit, during puncture and after puncture (return) was 2.0, 1.0 and $10.0 \mathrm{~mm} \mathrm{~s}^{-1}$, respectively.The average fruit height and the return distance of the probe after puncture were 28 and $35 \mathrm{~mm}$, respectively. The geometry of the probe used for the tests was the probe SMS $\mathrm{P} / 5 \mathrm{~S}$, without lubrication.

Data were submitted to analysis of variance, being the presuppositions of the Anova verified using the ShapiroWilk \& Bartllet test. The averages were compared by Tukey test at a 5\% probability level.

\section{RESULTS AND DISCUSSION}

The application of only water for the leaching of salts in the treatments T2 and $\mathrm{T} 3$ contributed to reduce the salinity of the substrate solution. In the tomato reproductive phase considered the most important one, the values of electrical conductivity and saline activity recorded in leached solution of the pots fertigated with treatments 2 and 3 , were 1.87, 0.86 $\mathrm{dS} \mathrm{m}^{-1}, 0.27$ and 0.28 , respectively, whereas the values in treatments 1 and 4 were $4.05,4.86 \mathrm{dS} \mathrm{m}^{-1}, 0.57$ and 0.28 , respectively (Table 1 ).

The highest electrical conductivity and saline activity values of the leached substrate solutions verified in treatments T1 and T4 (Table 1) show that part of the nutrients provided through fertigation was not completely absorbed by the plant. According to Katerji et al. (2003), during the reproductive phase, the electrical conductivity in the substrate should be kept below $2.5 \mathrm{dS}$ 
$\mathrm{m}^{-1}$. Nevertheless, under the growing conditions of the treatments mentioned, the salt concentration increase around the tomato roots (Andriolo et al., 2003) probably caused reduction in the osmotic potential of the solution with consequent reduction of the water and nutrients uptaken by the plant. Therefore, in order to avoid salinization, fertigation must be managed, monitoring the electrical conductivity of the solution more frequently, correcting it when necessary. Some studies show that it is possible to reuse the leached nutrient solution of the substrate in tomato cultivation without losses in fruit productivity, with maintenance of the electrical conductivity of the solution less than $4.9 \mathrm{dS} \mathrm{m}^{-1}$ (Andriolo et al., 2003), value which is close to the ones found in this study (Table 1).

The saline activity in the pot substrate in treatment T2 was higher when compared to treatment $\mathrm{T} 3$ only at 34 DAT and did not differ at 104 DAT and 126 DAT (Table 1). However, the electrical conductivity of percolated solution of treatment T2 was higher than in treatment T3 during the three periods analyzed. This fact probably occurred because the pots fertigated with treatment $\mathrm{T} 3$ were provided with an extra water irrigation depth in order to promote salt leaching before each fertigation.

The $\mathrm{pH}$ values of solutions percolated in pots fertigated according to treatments remained around 3.90 and 4.07 at 104 DAT and 126 DAT, respectively, and did not range significantly among treatments. The nutrient concentrations in standard and reused solutions were slightly higher than the theoretical concentrations of the standard solution in the vegetative and reproductive phases (Table 2). Total salt concentration in fertigation solution was higher than the theoretical concentration (Table 2) about $6.8 \%$ in vegetative phase and $25.1 \%$ in reproductive phase.

In reused solution, salt concentration surpassed the theoretical concentration $4.2 \%$ and $29.8 \%$. The increases in nutrient concentration in relation to theoretical concentrations may have occurred due to the variations normally found in nutrient concentrations in commercial fertilizers. However, this fact probably did not contribute to decrease tomato productivity, because even if an extreme change in the proportion among nutrients in the solution which produces deviations in nutrient uptake occurs, tomato crop has, genetically, high capacity to select ions to suit nutritional requirements (Furlani et al., 2013).

During vegetative phase (35 DAT), magnesium content found in the dry matter of the plant leaves which were under treatments $\mathrm{T} 1$ and $\mathrm{T} 4$ were the highest and did not differ among them (Table 2) and in plant leaves fertigated with the treatments characterized by water application to promote salt leaching (treatments T2 and T3), magnesium concentrations were lower and did not differ statistically. Magnesium concentrations found in the dry matter of tomato leaves were within the range considered normal for the crop (Alvarenga, 2013), regardless of treatment.

During reproductive phase (110 DAT), calcium concentration found in the dry matter of tomato leaves was significantly lower than the concentration found in the plant leaves which were under treatment 1 . Zinc content was the highest in this treatment and differred statistically from the contents found in the plants which were under the other treatments (Table 2 ). The lowest calcium content found in the plant leaves which were under treatment 1 can be explained by the highest salinity of substrate solution (Cuartero \& Muñoz, 1999), indicated by the high value of the electrical conductivity and saline activity (Table 1). According to Martinez et al. (1997), calcium is transported to various parts of the plant via xylem by the upward movement of the water, which may be through transpiration stream during the day or via root pressure at night. The high salt concentration in the substrate solution decreases the water potential and, consequently, water absorption and calcium translocation are compromised, and it may reduce the calcium content of leaves and fruits (Martinez et al., 1997).

In vegetative phase, contents of $\mathrm{K}$, $\mathrm{Ca}, \mathrm{Mg}, \mathrm{S}, \mathrm{Zn}, \mathrm{B}$ and $\mathrm{Fe}$ found in the dry matter of tomato leaves were considered in the normal range and contents of $\mathrm{Cu}$, $\mathrm{N}, \mathrm{P}$ and $\mathrm{Mn}$ were considered high, according to parameters for diagnosing nutritional status of tomato (Alvarenga, 2013). The high $\mathrm{Cu}$ content found in the leaves can be explained by the sprays of copper oxychloride after sprout thinning and defoliation, in order to avoid the

Table 1. Average values of the saline activity in substrate (SA), electrical conductivity (EC) and $\mathrm{pH}$ values of nutrient solution percolated in pots measured at 34, 104 and 126 days after transplanting (DAT). Goiânia, UFG, 2014.

\begin{tabular}{|c|c|c|c|c|c|c|c|c|}
\hline \multirow{3}{*}{ Treatments } & \multirow{2}{*}{\multicolumn{2}{|c|}{$\begin{array}{c}\text { Vegetative phase } \\
\text { 34 DAT } \\
\end{array}$}} & \multicolumn{6}{|c|}{ Reproductive phase } \\
\hline & & & \multicolumn{3}{|c|}{104 DAT } & \multicolumn{3}{|c|}{$126 \mathrm{DAT}$} \\
\hline & SA & $E C\left(d_{S} m^{-1}\right)$ & SA & $E C\left(d S m^{-1}\right)$ & pH & SA & $\mathrm{CE}\left(\mathrm{dS} \mathrm{m^{-1 } )}\right.$ & pH \\
\hline $\mathrm{T} 1$ & $0.45 a^{*}$ & $1.91 \mathrm{a}$ & $0.57 \mathrm{~b}$ & $4.05 \mathrm{~b}$ & $3.84 \mathrm{a}$ & $0.62 \mathrm{~b}$ & $3.63 \mathrm{~b}$ & $3.94 \mathrm{a}$ \\
\hline $\mathrm{T} 2$ & $0.38 \mathrm{~b}$ & $1.07 \mathrm{c}$ & $0.27 \mathrm{c}$ & $1.87 \mathrm{c}$ & $3.70 \mathrm{a}$ & $0.35 \mathrm{c}$ & $1.87 \mathrm{c}$ & $4.10 \mathrm{a}$ \\
\hline $\mathrm{T} 3$ & $0.19 \mathrm{c}$ & $0.39 \mathrm{~d}$ & $0.28 \mathrm{c}$ & $0.86 \mathrm{~d}$ & $4.02 \mathrm{a}$ & $0.33 \mathrm{c}$ & $0.99 \mathrm{~d}$ & $4.06 \mathrm{a}$ \\
\hline $\mathrm{T} 4$ & $0.43 \mathrm{a}$ & $1.54 \mathrm{~b}$ & $0.61 \mathrm{a}$ & $4.86 \mathrm{a}$ & $4.04 \mathrm{a}$ & $0.68 \mathrm{a}$ & $4.52 \mathrm{a}$ & $4.20 \mathrm{a}$ \\
\hline CV (\%) & 32.47 & 48.12 & 39.24 & 58.96 & 6.11 & 34.42 & 57.49 & 5.68 \\
\hline
\end{tabular}

*Averages followed by same letters in columns did not differ statistically among them, by Tukey test ( $<<0.05)$. T1 [(control)= fertigation with leaching of 20\%]; T2 = fertigation throughout the day and irrigation at the end of the day with need of leaching of $20 \%$; T3= irrigation with need of leaching of $20 \%$, followed by fertigation in all activations of the irrigation system; T4= fertigation with need of leaching of $20 \%$ and reuse of the leached solution. 
Table 2. Averages of magnesium concentrations at 35 days after transplanting (vegetative stage) and concentrations of calcium and zinc at 110 days after transplanting (reproductive stage) in leaves of tomato plants grown under different strategies of fertigation management. Goiânia, UFG, 2014.

\begin{tabular}{lccc}
\hline \multirow{2}{*}{ Treatments } & $\begin{array}{c}\text { Vegetative phase } \\
\text { Mg (\%) }\end{array}$ & \multicolumn{2}{c}{ Reproductive phase } \\
\cline { 3 - 4 } & $0.74 \mathrm{a}^{*}$ & $2.99 \mathrm{~b})$ & $\mathbf{Z n}\left(\mathbf{m g ~ \mathbf { ~ g ~ } ^ { - 1 } )}\right.$ \\
\hline T1 & $0.61 \mathrm{~b}$ & $3.38 \mathrm{a}$ & $61.6 \mathrm{a}$ \\
T2 & $0.62 \mathrm{~b}$ & $3.68 \mathrm{a}$ & $48.2 \mathrm{~b}$ \\
T3 & $3.51 \mathrm{a}$ & $47.6 \mathrm{~b}$ \\
T4 & $0.69 \mathrm{ab}$ & $42.4 \mathrm{~b}$ \\
\hline
\end{tabular}

*Averages followed by same letters in columns did not differ statistically among them, by Tukey test $(\mathrm{p}<0.05) . \mathrm{T} 1 \quad[(\mathrm{control})=$ fertigation with leaching of $20 \%]$; $\mathrm{T} 2=$ fertigation throughout the day and irrigation at the end of the day with need of leaching of $20 \%$; T3= irrigation with need of leaching of $20 \%$, followed by fertigation in all activations of the irrigation system; T4= fertigation with need of leaching of $20 \%$ and reuse of the leached solution.

Table 3. Average values obtained on minitomato fruits grown under different fertigation management. Goiânia, UFG, 2014.

\begin{tabular}{lcccc}
\hline Treatments & $\begin{array}{c}\text { Marketable } \\
\text { fruits (number } \\
\text { per plant) }\end{array}$ & $\begin{array}{c}\text { Commercial } \\
\text { production } \\
\text { (kg per plant) }\end{array}$ & $\begin{array}{c}\text { Fruits presenting } \\
\text { blossom-end rot } \\
\text { (number per plant) }\end{array}$ & $\begin{array}{c}\text { Total soluble } \\
\text { solids content } \\
\text { ( } \text { Brix) }\end{array}$ \\
\hline $\mathrm{T} 1$ & $131.15 \mathrm{ab}^{*}$ & $1401.90 \mathrm{ab}$ & $3.4 \mathrm{a}$ & $5.817 \mathrm{a}$ \\
$\mathrm{T} 2$ & $136.85 \mathrm{ab}$ & $1460.30 \mathrm{ab}$ & $1.5 \mathrm{ab}$ & $5.443 \mathrm{c}$ \\
$\mathrm{T} 3$ & $125.40 \mathrm{~b}$ & $1342.30 \mathrm{~b}$ & $0.55 \mathrm{~b}$ & $5.467 \mathrm{c}$ \\
$\mathrm{T} 4$ & $156.05 \mathrm{a}$ & $1616.85 \mathrm{a}$ & $3.3 \mathrm{a}$ & $5.652 \mathrm{~b}$ \\
\hline $\mathrm{CV}(\%)$ & 26.09 & 24.12 & - & 4.2 \\
\hline
\end{tabular}

*Averages followed by same letters in columns did not differ statistically among them, by Tukey test $(\mathrm{p}<0.05)$.T1 [ $($ control $)=$ fertigation with leaching of $20 \%] ; \mathrm{T} 2=$ fertigation throughout the day and irrigation at the end of the day with need of leaching of $20 \%$; T3= irrigation with need of leaching of $20 \%$, followed by fertigation in all activations of the irrigation system; T4= fertigation with need of leaching of $20 \%$ and reuse of the leached solution.

occurrence of diseases. However, according to Alvarenga (2013), the leaf contents of $\mathrm{N}, \mathrm{Ca}$ and $\mathrm{Zn}$ were considered in the normal range during the reproductive phase (110 DAT), whereas the contents of $\mathrm{K}, \mathrm{Mg}, \mathrm{B}, \mathrm{Mn}$ and $\mathrm{Fe}$ were considered high; and the contents of $\mathrm{P}, \mathrm{S}$ and $\mathrm{Cu}$ were considered to be in excess.

High concentrations of $\mathrm{K}$ and $\mathrm{Mg}$ in nutrient solution in relation to the theoretical concentration of standard nutrient solution for vegetative phase and high contents of these elements in tomato leaves, found in the same phase, indicate that the authors noticed an advantageous competition with calcium, since the absorption of this nutrient decreases in a medium containing high concentrations of $\mathrm{K}$ and $\mathrm{Mg}$ (Malavolta, 1980). And as $\mathrm{Ca}$ and $\mathrm{Mg}$ have an inhibitory effect of $\mathrm{Zn}$ root absorption (Malavolta, 1980), the lowest Ca concentration in tomato leaves under electrical conductivities of the nutrient solution applied were between 2.0 and $2.2 \mathrm{dS} \mathrm{m}^{-1}$, considering that the highest value of $\mathrm{EC}$ of the percolated solution of the pots, verified at 104 DAT under treatment T4, was $4.86 \mathrm{dS} \mathrm{m}^{-1}$ (Table 1).

Total production (average of 1.99 $\mathrm{kg}$ per plant), the number of fruits per plant (average of 184.4) and fruit mass (average of $10.4 \mathrm{~g}$ ) were not significantly influenced by the treatments. These values are close to ones considered normal for tomato production of the same hybrid (Gusmão et al., 2006). The average fruit mass is also similar to $12 \mathrm{~g}$ reported by Alvarenga (2013) for marketable grape mini tomato variety.

In relation to number and production of commercial fruits, the authors verified significant differences among treatments. Plants which were under treatments $\mathrm{T} 4, \mathrm{~T} 2$ and $\mathrm{T} 1$ produced greater number of commercial fruits per plant and higher commercial production per plant (Table 3). However, the authors did not observe any significant difference of commercial production among treatments $\mathrm{T} 1, \mathrm{~T} 2$ and $\mathrm{T} 3$. The average commercial productivity showed in treatment $\mathrm{T} 3$ was positively influenced due to the reduction of the incidence of blossom-end rot of fruits (Table 3). Considering that the authors used lower amounts of fertilizers in treatments $\mathrm{T} 2$ and $\mathrm{T} 4$ in relation to treatment $\mathrm{T} 1$ and the equivalence in the commercial production of the fruits, the strategies proposed in these treatments are alternatives for fertigation management aiming to reduce production costs without reducing production.

The average of cracked fruits (average of 33.65 fruits per plant) and very small fruits (average of 6.7 fruits per plant) were not influenced by the treatments. The treatments influenced the number of fruits presenting blossom-end rot (Table 3 ), whereas the number of cracked and very small fruits (fruits weighing less than $5.0 \mathrm{~g}$ ) were not influenced by the treatments. On average, $25.5 \%$ of the fruits presented defects and were considered unmarketable. The occurrence of cracking (35.55 fruits 
per plant), equivalent to $19.8 \%$ of total fruits, was higher when compared to the other defects $(0.12 \%$ for fruits presenting blossom-end rot and $0.35 \%$ for very small fruits) and, consequently, that was what most influenced the losses of unmarketable fruits.

Blossom-end rot incidence was higher in fruits of plants which were under treatments T1 and T4. Blossomend rot is a symptom of a physiological disorder caused by a deficiency of calcium at the distal end of the fruit (Silva \& Giordano, 2000). Reduction in calcium absorption related to the salinity increase in the growing medium may have been the cause of this physiological disorder in treatment T1. In contrast, in treatment T4, the authors verified leaf $\mathrm{Ca}$ contents equivalent to the treatments T2 and T3 despite the high values of EC and AS. However, during reproductive phase, the authors observed that $\mathrm{Ca}$ contents in the solution applied in treatment T4 were, on average, $11.9 \%$ higher than the indices presented in standard nutrient solution (data not shown), showing that a lower absorption of this nutrient by the plants which were under treatment T4 was observed.

Morphological traits of the fruits harvested in full maturation phase (89 DAT) and color parameters were not influenced by the treatments. Both morphological traits and color of the fruits (on average, red color) harvested are within a range which was considered acceptable for the grape mini tomato market (Alvarenga, 2013; Vieira et al., 2014). The authors highlight that among these traits, color is the most important attribute for the consumer when buying tomatoes commercialized in closed transparent packaging (Luiz, 2005).

Among the organoleptic characteristics of mini tomato fruits, total soluble solids content was the only variable influenced by the treatments (Table 3). The applications of treatments $\mathrm{T} 1$ and $\mathrm{T} 4$ resulted in production of fruits with higher soluble solids content. However, these values were a little lower than generally found for the majority of cultivars of grape-type tomato, higher than $6^{\circ}$ Brix (Alvarenga, 2013).

Soluble solids content reflects fruit sweetness and indicates degree of maturity or fruit maturity (Vieira et al., 2014). Approximately $65 \%$ of total soluble solids consist of sucrose, glucose and fructose which are accumulated during final maturation phase (Lourenço, 2011). The differential characteristic of mini tomates, especially grape type, is related to low acidity and high soluble solids content (Alvarenga, 2013).

Average values of titratable acidity (average of $0.57 \%$ ) and $\mathrm{pH}$ (average of 3.89) were within optimal range for commercialization, which for titratable acidity ranged around $0.40 \%$ and $\mathrm{pH}$ from 3.7 to 4.5 (Vieira et al., 2014). Titratable acidity, $\mathrm{pH}$ and soluble solids content are indicators used to evaluate food during the postharvest period (Chitarra \& Chitarra, 2005). These indicators define consumer acceptance of a product, since excessively acid or low $\mathrm{pH}$ fruits are generally less accepted by the consumer (Vieira et al., 2014).

The authors conclude that the fertigation managements tested did not influence the tomato vegetative development, number and mass of fruits per plant, fruit cracking, titratable acidity and $\mathrm{pH}$ of the pulp. The use of standard nutrient solution with $20 \%$ leaching fraction (treatment T1) and the reuse of percolated solution, also with 20\% leaching fraction (treatment T4), provided higher commercial production, even increasing the incidence of blossom-end rot, and higher soluble solids content in mini tomato pulp.

\section{REFERENCES}

ALVARENGA, MAR. 2013. Tomate: produção em campo, em casa de vegetação e em hidroponia. Lavras: UFLA. 457p.

ANDRIOLO, JL; WITTER, M; ROSS, TD; GODÓI, RS. 2003. Crescimento e desenvolvimento do tomateiro cultivado em substrato com reutilização da solução nutritiva drenada. Horticultura Brasileira 21: 485-489.

AYERS, RS; WESTCOT, DW. 1985. Water quality for agriculture. Rome: FAO. 97p.

BRASIL. Ministério da Agricultura, Pecuária e Abastecimento. Instrução Normativa SDA $\mathrm{n}^{\circ} 17$ de 24 de mai. 2002. Métodos analíticos oficiais para análise de substratos para plantas e condicionadores de solo. Diário Oficial da União, Brasília, DF, 24 maio 2007, Seção 1, p. 3-5.

CALBO, AG; SILVA, WLC. 2005. Sistema Irrigas para Manejo de Irrigação: Fundamentos, aplicações e desenvolvimentos. Brasília: Embrapa, 163p.

CHITARRA, MIF; CHITARRA, AB. 2005. Póscolheita de frutas e hortaliças: fisiologia e manuseio. Lavras: UFLA. 785 p.

CUARTERO, J; MUÑOZ, RF. 1999. Tomato and salinity. Scientia Horticulturae 78: 83-125.

ELOI, WM; DUARTE, SN; SOARES, TM. 2007. Níveis de salinidade e manejo da fertirrigação sobre características do tomateiro cultivado em ambiente protegido. Agrária 2: 83-89.

FERMINO, MH. 2014. Substratos: composição, caracterização e métodos de análise. Guaíba: Agrolivros, 111p.

FERNANDES, C; CORÁ, JE; BRAZ, LT. 2007. Classificação de tomate-cereja em função do tamanho e peso dos frutos. Horticultura Brasileira 25: 275-278.

FURLANI, PR; FAQUIN, V; ALVARENGA, MAR; SENO, S. 2013. Produção em substratos e em hidroponia. In: ALVARENGA, MAR (ed). Tomate: produção em campo, em casa de vegetação e em hidroponia. Lavras: UFLA. p.245-273.

GUSMÃO, MTA; GUSMÃO, SAL; ARAÚJO, JAC. 2006. Produtividade de tomate tipo cereja cultivado em ambiente protegido e em diferentes substratos. Horticultura Brasileira 24: 431-436.

KATERJI, N; HOORN, JW; HAMDY, A; MASTRORILLI, M. 2003. Salinity effect on crop development and yield, analysis of salt tolerance according to several classification methods. Agricultural Water Management 62: 37-66.

LOURENÇO, GA. 2011. Desidratação parcial de tomate cereja em secador de bandejas vibradas com reciclo. Uberlândia: UFU. 95p (Dissertação mestrado).

LUIZ, KMB. 2005. Avaliação das características físico-químicas e sensoriais de tomates (Lycopersicum esculentum Mill) armazenados em refrigeradores domésticos. Florianópolis: UFSC. 107p (Dissertação mestrado).

MAGÁN, JJ; GALLARDO, M; THOMPSON, RB; LORENZO, P. 2008. Effects of salinity on fruit yield and quality of tomato grown in soilless culture in greenhouses in Mediterranean climatic conditions. Agricultural Water Management 95: 1041-1055.

MALAVOLTA, E. Elementos de nutrição mineral de plantas. 1980. São Paulo: Agronômica Ceres. 251p.

MARTINEZ, HEP; BRACCINI, MCL; BRACCINI, AL. 1997. Cultivo hidropônico do tomateiro (Lycopersicon esculentum Mill.). Unimar 19: 721-740.

PAUCAR-MENACHO, LM; SILVA, LH; BARRETO, PAA; MAZAL, G; FAKHOURI, FM; STEEL, CJE; COLLARES-QUEIROZ, FP. 2008. Desenvolvimento de massa alimentícia fresca funcional com a adição de isolado protéico de soja e polidextrose utilizando páprica como corante. Ciência e Tecnologia de Alimentos 28: 767-778.

RODRIGUES, LRF. 2002. Técnicas de cultivo hidropônico e de controle ambiental no manejo de pragas, doenças e nutrição vegetal em ambiente protegido. Jaboticabal: Funep. 762p.

SILVA, JBC; GIORDANO, LB. 2000. Tomate para processamento industrial. Brasília: Embrapa Hortaliças. 168p.

VIEIRA, DAP; CARDOSO, KCR; DOURADO, KKF; CALIARI, M; SOARES JÚNIOR, MS. 2014. Qualidade física e química de minitomates SweetGrape produzidos em cultivo orgânico e convencional. Revista Verde 9: 100-108. 